\title{
Developing A Learning Trajectory for Teaching Set in Secondary Grade
}

\author{
$1^{\text {st }}$ Yulia \\ Matematics Department \\ UIN Imam Bonjol Padang \\ Padang, Indonesia \\ yuliayo99@ymail.com
}

\author{
$2^{\text {nd }}$ Ahmad Fauzan \\ Post Graduate Program \\ Universitas Negeri Padang \\ Padang, Indonesia \\ $4^{\text {th }}$ Yerizon \\ Post Graduate Program \\ Universitas Negeri Padang \\ Padang, Indonesia
}

\author{
$3^{\text {rd }}$ Nurhizrah Gistituati \\ Post Graduate Program \\ Universitas Negeri Padang \\ Padang, Indonesia
}

\begin{abstract}
This study aimed to develop a learning trajectory (LT) for teaching sets using Realistic Mathematics Education (RME) approach and to investigate its influence on student ability. The LT was developed through a design research which consisted of a cyclic process of preparing for the experiment, conducting the experiment, and retrospective analysis. The subject of the study was students at grade VII in Padang. Data were collected through direct observation, interview, and check list, videotaping, and analyzing the work of the students. The LT was evaluated through one-to-one and small group evaluation before it be tried out in a test. The whole strategy (emergent modeling) showed the construction and contribution of the students in discovering the concept of sets from the informal to the formal level. It could help the students to reinvent sets concept. Finally, we discovered that the students increased their mathematics creative thinking ability.
\end{abstract} Sets

Keywords-Design Research, Learning Trajectory, RME,

\section{INTRODUCTION}

The topic about set is given at the basic level because it is an important topic for all branches of mathematic, as the basis of more complex mathematics concepts and as the basis of mathematics reasoning [1]. This is similar to that of namely logic and sets of form the foundation of mathematics[2]. Mathematics learning, especially set learning should be able to develop the ability of creative thinking. However, based on interviews with mathematics teachers of MTsN 5 Padang, MTsN 4 Padang and SMP 41 Padang, students are still difficult to understand the set, there are still students who have not been able to understand the set and not the set, draw Venn diagram, difficulty in completing the routine problem, questions that demand students' creative thinking skills such as contextual matters, problem-solving problems related to the set, questions of reasoning, and communication matters. The difficulty is because students are less able to define and clarify information that is on the problem and less able to determine solutions and conclusions. In addition, students are also less able to provide new ideas and provide an alternative answer to the questions given. It shows the students' critical and creative thinking ability is still in low level. It ultimately affects the low student mathematics score[3]. This is in line with the proposed by Lee Peng Yee and Lee Ngan Hoe
(2009) that students are still difficult in learning the topic of set.

One of the factors that determine the success of students in the process of learning mathematics is the design of learning prepared by the teacher. The teacher has designed the lesson by putting it into the Lesson Plan (RPP) in accordance with the 2013 curriculum, which includes teacher activities and student activities. Seen in the RPP, there has been no prediction or prediction of student responses during the lesson. The lesson plans made by teachers are usually less consideration of the responses given by the students so that the later learning series may not be matched by the different learning trajectory of each student[4]. By knowing the responses of students, the teachers could actually choose the right way to achieve the successful learning process.

Based on observations during the learning process, teachers rarely carry out learning in accordance with the RPP that has been made. Teachers more often carry out the learning by following the sequence of material contained in textbooks. Teachers explain learning materials, give examples of problems and provide practice to students. Learning is ultimately beyond the RPP that has been designed and re-centered on the teacher. Teachers have been trying to involve students actively through group learning. Students have a willingness to discuss, but have not created an optimal interaction in solving problems related to finding and understanding the concepts that exist in mathematics. Learning rarely begins with problems related to the knowledge that students already have. Learning that begins with problems related to the knowledge they already have will allow students to rediscover the concepts of mathematics that are being studied, will make students more active and more likely to develop their mathematics thinking skills. Those are in line that mathematics learning in schools is still dominated by teachers and the results of mathematics learning in schools have not shown satisfactory results[20]. Another problem seen is that students do not have a handbook in learning. Students only accept what is given by the teacher, record and guided by the note. Such a condition is also a factor in the weakness of students' mathematics thinking ability.

The students' learning process and their level of thinking should give the teacher a working framework in 
oder to develop such knowledge about students' thinking and learning. An instructional design which is based on students learning trajectory is known by Hypothetical Learning Trajectory (HLT). HLT is a kind of process that consists of learning goal, learning activity and hypothesis of learning process to predict how students think and comprehend during the context of learning activity [5]. Some researchers showed that hypothetical learning trajectory (HLT) can improve students' comprehension [6] [7] [8]. The other researches showed that HLT did not only improve students' comprehension but also improved students' mathematics thinking ability, just as the research done by Graveimeijer [9] that proves that HLT by using RME helps the teachers in developing a good local instructional theory for a topic lesson and also help students in developing their thinking ability such as analysis and the other mathematics thinking ability.

One of the approaches that can be used in designing HLT is through realistic mathematics education (RME). RME is one of approaches in mathematics learning process that contains constructive, interactive and reflective components. In RME, mathematics is seen as human activities [10][11][21][22]. Mathematics is not transferred to the students as a product, but the students should construct it by themselves through contextual problem solving that is interactive, whether it is formal or informal, so that the students can find it by themselves, without a teacher.

There are several steps taken in designing RME-based HLT among others undertaking preliminary research covering needs analysis, literature review, determining learning objectives, determining learners' learning activities, learning process hypotheses. Next design and design prototype HLT, conduct formative evaluation, retrospective analysis. The final step is to conduct a summative evaluation. This paper is limited to the development of learning trajectory and sees the improvement of students' creative thinking ability.

\section{EASE OF USE}

An instructional design in terms of HLT consists of three components; learning goal, task of learning activity and hypothesis of how the students learn and think (Simon, 1995). Setting the learning activities are based on RME. Those activities give a chance for the students to reinvent mathematics through teacher's guide (Graveimejer, 1994)[11]. The activity RME-based concerns on RME characteristics, they are: 1) the use of contexts, 2) the use of models, 3) the use of students own production and contructions, 4) the interactive character of teaching process, and 5) the interviewments of various learning strands. (Gravemeijer, 1994).

In designing and developing HLT RME-based in this research, review of previous researches is needed. The researches related to the development of instructional design in form of HLT RME-based have done previously by many researchers, sucha $\mathrm{s}$ a research done by Web[12]. In this research, Webb designed HLT RME-based to introduce the concept of logarithm. Web used contextual problem in form of height of poni and the growth of E.Coli bacteria. This contextual problem gives a possibility for the students to do informal mathematicsematism process, that later will improve into formal mathematicsematism process by giving problem in mathematics. These informal and formal mathematicsematism processes help the stduents in comprheending the concept of logarithm. The use of RME in Cobb' research proves that learning RME-based builds students-centered learning.

The other research is conducted by Hidayat and Iksan [13]. This research was aimed to see the effect of RME toward the comprehension of studnets' linier program concept. It was a kind of quasi experimental nonequivalent, pretest and posttest control group design. This research had control class and experiment class. The result of this research shows that the use of RME by using contextual problems help the students to have a better comprehension oflinier program concept.

The research related to designing HLT is also conducted by Prahmana and Kusumah [14]. This research developed HLT in the research of mathematics education by using research based learning. In developing HLT, the researcher used Graveimeijer 's and Cobb's model. HLT consists of three components; (1) the purpose of mathematics teaching for students, (2) learning activities, device or media used in the learning process, and (3) a conjecture of understanding the process of learning how to learn and strategies students that arise and thrive when learning activities are done in Class (Graveimejer, 2004). The aim of this research is to improve research ability and academic writing for pre-service teacher of mathematics. The other research that related to HLT and RME is conducted by Ozkaya and Karaca [15] about The Effect of Realistic Mathematics Education on Students' Achievements and Attitude In Fifth Grades Mathematics Courses, the research done by Silseth[16] about The Multivoicedness of game Playing: Exploring the Unfolding of a students'learning trajectory in a gaming context at school, and the research conducted by Rees [17] about Developing specialist expertise:an unanticipated learning trajectory.

Based on those researches above, the research in this paper focuses on the development of instructional design in terms of learning process RME-based in sets materials for students at grade VII of junior high school. In planning the process of the research, it was also used the model proposed by Graveimeijer and Cobb. HLT also consists of three components proposed by Graveimeijer. By designing the learning process RME-based, it can build students-centered learning, develop students' ability in problem solving, and help the students to use the concept they have in inventing new concept. Thus, the instructional design RME-based will revise and develop students' ability.

\section{METHODS}

This research is a development research using Plomp model [18] and Gravemeijer \& Cobb [19]. To develop the learning path, we followed Gravemeijer and Cobb. The Gravemeijer and Cobb model consists of three phases: preparing for the experiment phase, conducting the experiment and analysis retrospective. The Plomp model consists of three phases: the preliminary research phase, the prototyping stage and the assessment phase. This paper 
focused on preliminary research consisting of needs analysis, curriculum analysis and literature review. Based on preliminary research results, the learning path line of the RME-based subject set and for its operations is designed for student books and teachers' books.

In the prototyping stage phase, the prototype has been made through an evaluation of formative form which consists of self evaluation conducted by the researcher himself, validation by expert, focus group discussion, one to one, small group, and field test. In the assessment phase, a creative thinking skill test was conducted to grade 5 students of MTsN 5 Padang to see effectiveness. The research data is collected through validation sheet, teacher and student response questionnaire, learning trajectory learning sheet, consciousness sheet and creative thinking ability test.

\section{RESULT AND DISCUSSION}

\section{A. The Result of Prototyping Phase}

\section{1) The Design of Hypothetical Learning Trajectory (HLT)}

Hypothetical learning trajectory (HLT) consists of three parts; one of them is the purpose of HLT that consists of three components, they are learning goal for meaningful learning, a collection of task for achieving the goal, and hypothesis of how students learn and think (Simon, 1995). The learning goal is the students' target after they accomplish mathematics concept that has been decided, and then students' activity is designed including the prediction of students' answer, from the simple up to the more complex ones. This activity is expected to help the students in developing their mathematics ability horizontally into vertical mathematics. The following is the rationale of HLT designed:

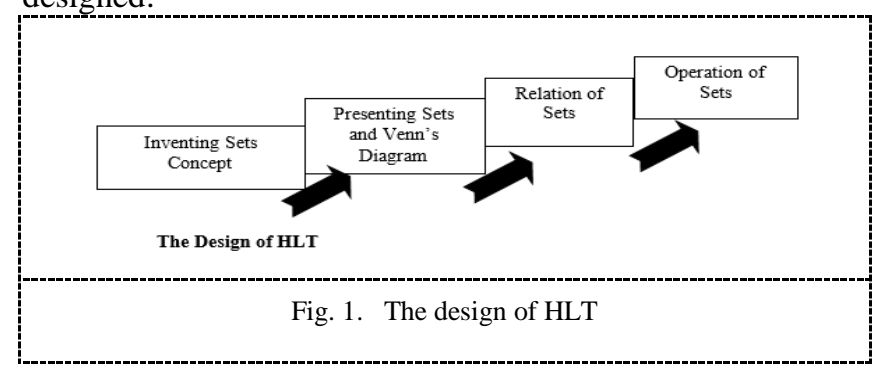

Based on the design of HLT above, there are four HLT that are designed, they are inventing sets concept, the activity is to collect the data of students at grade VII of junior high school in order to classify object based on such characteristics. The second activity is classifying the students based on their own characteristics. It is aimed to build a problem that can stimulate the students to invent the different among sets and non-sets, blank sets and universal sets, because these problems give a chance for the students to classify the good and bad students. From the first and second activity, the students get the description in grouping the object, stating the reason in grouping the object and stating the group member and non member. After that, the students are asked to solve the problem in which how to add the groups into the general activity of sets concept. At this stage, the students have been familiar to group the object and state it into mathematics.

Second, presenting set, the first activity is collect the data of stationary that usually used by the students in order to stimulate the students to present set by writing the members of sets creator. The second activity, the students are given contextual problem in deciding the animal group based on their characteristics. Those animal groups can be seen as a set that has animals as the members with their own characteristics. For the third activity, the students are given problems related to students' numbers group that they have commonly learned. Grouping numbers can be seen as a set. All the activities above lead the students to present the set in their real life. Through this activity, the students in the group interact to create a pattern in presenting set based on the first presentation up to the last one.

Third, sets relation, the activity is related to contextual problems about representation of the class to follow the best student's competition. The students are asked to make the possible formation of students who can represent the class. The formation can also be seen as a set. The second activity is given a challenge for the students to choose a decision. The decision taken is based on their knowledge of set. The problem is designed to help the students invent the concept of the same set and equivalent set. Based on the first and second activity, the student are expected to understand sets relation, they are partial set, equal set, disjoint sets and power of set and equivalent set. The teacher facilitates the students during the class discussion to take a decision and strengthen the conclusion by giving such explanation of set relation.

Fourth, set operation, the activity is giving problem related to fruits. The problem stimulates the students to invent the concept of two sets operations by comparing the members of set that are operated. The second activity is inventing the characteristics of set operation through problems related to extracurricular activity. The problem stimulates the students to invent the principle of inclusion exclusion of two sets operation by comparing the members of each of the groups operated and also the other characteristics that links to each of the set operation.

\section{2) The design of teacher's book and students' book}

The teacher's book designed in this RME learning has some components. It includes HLT rationale, student's activity, time allocation, about mathematics, homework media, plans of students' evaluation, lesson plan and the conclusion. In other side, the students' book has some components; learning goal, students' activity, contextual problem and comprehension test.

\section{B. Formative Evaluation}

Formative evaluation is done to assess the quality of product design results developed. To assess the quality of HLT design results, teacher books, and student books using formative evaluation developed by Tessmer consisting of expert validation, one to one, small group or simple evaluation or micro evaluation), and field test (field test)[16]. At self evaluation stage used self evaluation sheet. Self evaluation is done on HLT, Master's Book Design and Student's Book Design. Errors in HLT include selection of contextual problems, on typing errors, unclear sentences and punctuation errors. Mistakes on Master's Book Design include errors in presentation, color and image feasibility to 
support contextual issues. Error in the other Student Books Literature design, color selection, display and typing.

\section{Results of Design Learning Validation}

After the self-evaluation, the next HLT, teacher book and student book validated by 5 validators are 2 lecturers of mathematics, 2 lecturers of education technology and 1 lecturer of Indonesian language. Based on the validation results validation values for HLT are 0.90 , teacher books 0.87 , and student books 0.91 . This indicates that the product developed is valid.

\section{Results of Practical Learning Design.}

After all the products developed are categorized as valid, then one-to-one evaluation is done with three students of grade VII MTsN 5 Padang with low, medium and high ability. The meetings are held individually with 2 hours lesson informally, and then informal interviews are conducted. Furthermore, informal interviews are conducted to ask students to respond to the learning flow in the book. Based on the results of interviews with students at the oneto-one evaluation stage, in general students with high ability, moderate and low can understand the contextual problems presented in contextual problems that serve as starting point in finding each concept.

After a revision of individual evaluation results, a small group evaluation (small group) is also called first cycle conducting experiment on the development of Gravemeijer \& Cobb model. This small group evaluation was conducted on 6 high school students of grade 5, medium and low grade VII MTsN 5 Padang. Overall the RME-based topic-based learning design can already be used. However, there are some things that need to be revised, including improvements in the contextual sentences given to the activity. Large group trials (field tests) are also called second cycle conducting experiments. This learning begins with class discussions, the students sit in groups of 4 students, and start to discuss with peers (pairs). Discussion of this class in addition to aims to build and develop student interactivity in accordance with the characteristics of the four RME, as well as a basic knowledge of students about the concept of the Set. The findings of the concept of the set in this study were conducted through the provision of activities to determine student data in the class. Various solutions provided by students in solving this problem are:

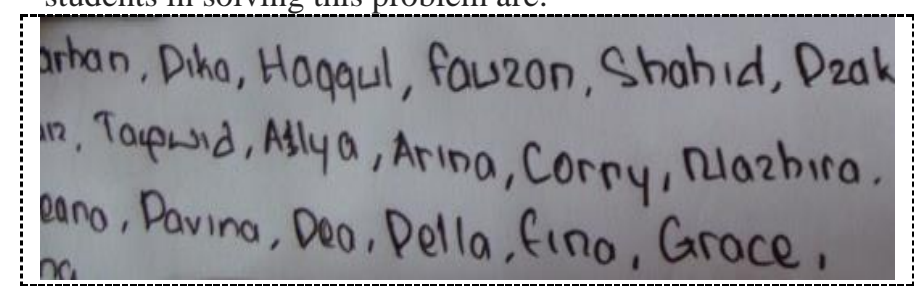

Fig. 2. Student's Answer

Students present in sequence form, this becomes the beginning for students in understanding the set as a collection of objects. The teacher asks whether students from other classes go into the data students create, whether students can register members according to the given problem. With that question the student understands that the name written is the name of a classmate, according to what is requested. This is the beginning of the students understanding that the concept of the set as a set of clearly defined objects. To find a concept rather than a set, it is given the problem of determining a group member of a set. Each student has a different answer. This is the beginning of students' understanding of non-sets. The teacher asks the students to compare with the answer to the previous problem, asking the question why the answers among the students vary, in contrast to the previously created set where all students give the same answer. Students respond because according to their judgment, beautiful and handsome students vary. This will make students understand that a collection of objects is called a set if clearly defined. To present Venn sets and diagrams, an activity is given to present the set by referring members, presenting the set through the properties of its members and presenting the set with the forming notation.

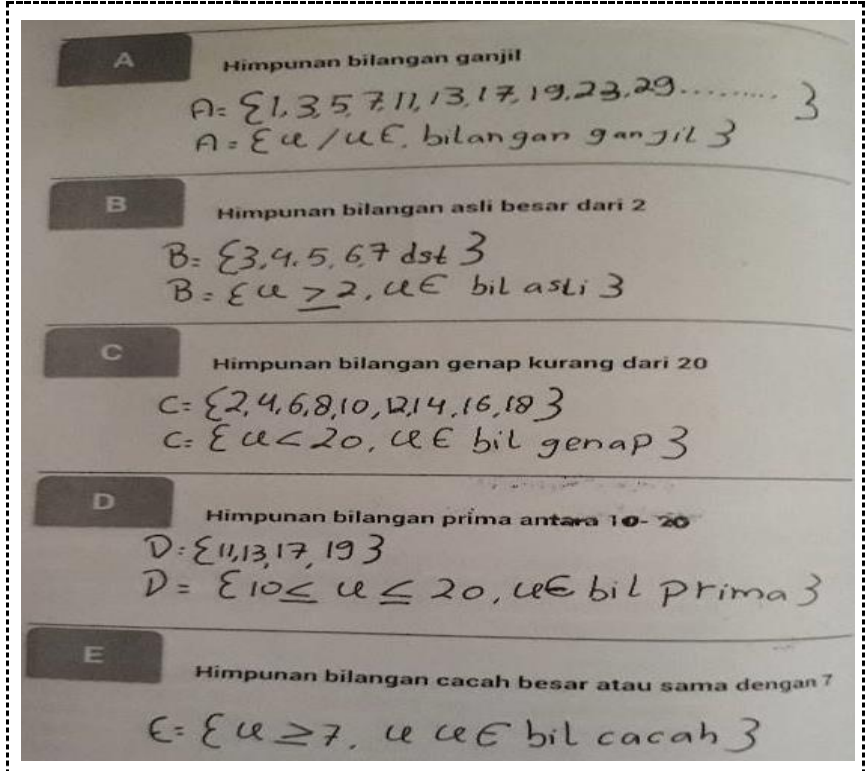

Fig. 3. Student's Answer

From the student's answer above is seen that there are students who first register the requested member. Based on the question and the teacher's direction the students have started to make using notation. The teacher then agrees with the students how to present the set using the complete set-up notation. To understand Venn diagrams, problems are drawn from the activities students perform in presenting the set. Students are asked to restate some sets that have the same members into a diagram

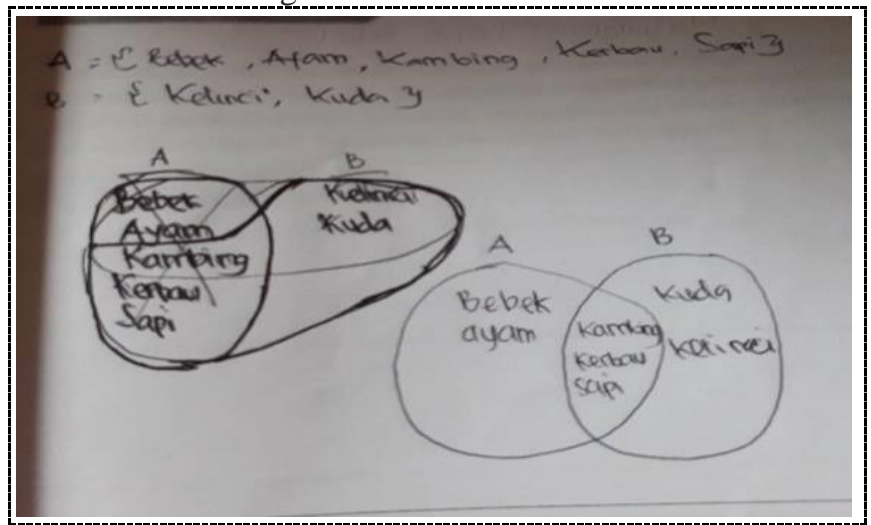

Fig. 4. Student's Answer 
TABLE II. RESUlTS PRACTICALITY By TEACHERS start to develop their thinking ability in making a diagram, initially the students make diagrams that are not yet compatible with the Venn diagram, but they understand the intended purpose. After the teacher gives directions how to make a better diagram, students can already improve to the better. Teachers with students make agreement on how to make the right Venn diagram and what elements of the Venn diagram.

To determine the Principles and the properties of the set operation are given problems about student's passion for sports. Based on the survey results students are asked to answer some questions.

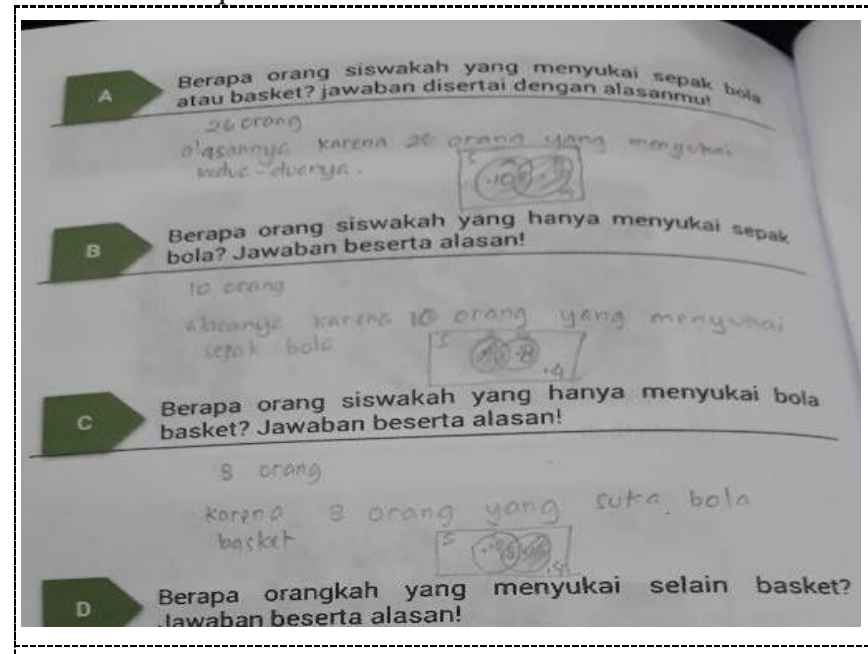

Fig. 5. Student' Answer

From the answers given by the students it appears that the students have used Venn diagrams to determine the answers to the questions asked. But not all students are using this Venn diagram. There are still students who decide by using ordinary operations. The teacher reminds students who have not used Venn diagrams about the previous lesson. Teachers with students make agreement on the nature of set operations. The followings are the results:

TABLE I. RESUlts PRACTICALITY By StUdENTS

\begin{tabular}{llcl}
\hline No & \multicolumn{1}{c}{ Rated aspect } & $\begin{array}{c}\text { Mean Value of } \\
\text { Practicality }\end{array}$ & Category \\
\hline 1 & Attractiveness & 0,83 & Very practical \\
2 & Process Usage & 0.86 & Very practical \\
3 & Ease of Use & 0.83 & Very practical \\
4 & Time efficiency & 0.83 & Very practical \\
& Value of Practicality & $\mathbf{0 . 8 4}$ & Very practical \\
\hline
\end{tabular}

Practical value of learning design topic of the set obtained from student questionnaire is 0.84 with practical categories based on practicality criteria. From the result of questionnaire analysis filled by the students, the design of learning set topic is easy to use, interesting, well understood, can motivate students to learn mathematics and find the concept well. Thus it can be concluded that students consider the subject-based subject RME learning design is practically used on topic Set class VII SMP / MTs.

\begin{tabular}{llcl}
\hline No & \multicolumn{1}{c}{ Rated aspect } & $\begin{array}{c}\text { Mean Value of } \\
\text { Practicality }\end{array}$ & Category \\
\hline 1 & Attractiveness & 0,84 & Very practical \\
2 & Process Usage & 0.88 & Very practical \\
3 & Ease of Use & 0.88 & Very practical \\
4 & Time efficiency & 0.85 & Very practical \\
& Value of Practicality & $\mathbf{0 . 8 6}$ & Very practical \\
\hline
\end{tabular}

Practical value of learning design topic of the set obtained from the teacher questionnaire is 0.86 with a very practical category based on the criteria of practicality. Thus it can be concluded that the teacher considers the design of learning topic based set RME is practically used on topic set class IX SMP / MTs.

\section{Results of Learning Design Effectiveness.}

The effectiveness of RME-based subject learning design is seen from the results of students' mathematics creative ability test. This ability of mathematics creative thinking can be seen from the fluency / eloquence of creating new ideas, Originality, flexibility, Elaboration. The processes that occur in finding the concept of the set of each student vary. With the learning method applied, students can discuss and exchange opinions. The variation in the answers and opinions expressed by students indicates that students' mathematics creative thinking is increasing when compared to previous learning.

TABLE III. The RESUlt OF THE TeSt OF CREATIVE ThINKING ABILITY

\begin{tabular}{llcc}
\hline No & $\begin{array}{c}\text { Indicator of Creative } \\
\text { Thinking Ability }\end{array}$ & Percentage & Note \\
\hline 1 & Flexibility & 80,5 & very successful \\
2 & Originality & 76,5 & successful \\
3 & Flexibility & 78.3 & very successful \\
4 & Elaborative & 80.5 & very successful \\
& & 78.95 & Very successful \\
\hline
\end{tabular}

The successful achievement of students` mathematics creative thinking ability is $78,95 \%$ with very successful criteria and the average result of students' creative thinking ability test is 78,4 with successful criteria. Thus, it is concluded that the design of subject matter learning based on RME class VII SMP / MTsN, this effective impact on students' mathematics creative thinking ability. After the learning process ends, researchers, teachers, and observers discuss the extent to which the implementation of learning trajectory. The whole learning trajectory topic of this RMEbased set is already used for set learning.

\section{CONCLUSION}

The instructional design in form of RME in set materials for students at grade VII of junior high school is based on the result of preliminary research that produces HLT, teacher's book and students' book. HLT consists of learning goal, activity, and hypothesis of how students learn. For operational of learning, HLT is created in form of teacher's book and students' book. This paper is limited on preliminary research, the development of HLT design, teacher's book and students' book. The evaluation that has been conducted is also still limited on self-evaluation. The 
next research is suggested to conduct the test for validity and practicality of teacher's book and students' book. The evaluation stage of the instructional design can be done to see students' comprehension or students' level of thinking.

\section{REFERENCES}

[1] Lee Peng Yee \& Lee Ngan Hoe, Teaching Secondary School Mathematics. A Resource book ( $2{ }^{\text {nd }}$ ed), Singapore: McGraw-Hill Education, 2009.

[2] Barnet. R. A., Ziegler. M. R \& Byleen. K. E., Finite Mathematics For Business, Economics, Life Sciences, and Sosial Sciences, New Jersey: Pearson Education Inc, 2008.

[3] Asui Nelson Chukwuyenum, "Impact of Critical Thingking on Performance in Matehmatics among Senior Secondary School Students in Lagos State", IOSR Journal of Research \& Method in Education, Volume 3 Issues 5, 2013, 18-25.

[4] Suryadi. D., "Didactical Design Research (DDR) dalam Pengembagan Pembelajaran Matematika In Bandung" Seminar Nasional Pembelajaran MIPA di UM Malang, 2010.

[5] Simon. Martin A., "Reconstructing Mathematics Pedagogy From A Constructivist Perspective", Journal of Research in Mathematics Education, Volume 26, No.2, 1995, 135-137.

[6] Baker. Arthur, Design Research on How IT May Support the Development of Symbols and Meaning in Mathematics Education, Freudenthal Institute, Utrecht University, 2003.

[7] Bardsley M. E., Pre-Kindergarten Teachers' and Understanding of Hyphotetical Learning Trajectories in Mathematics Education, Utrecht: University of Utrecht, 2006.

[8] Hadi. Sutarto, Pendidikan Matematika Realistik, Tulip Banjarmasin, 2005.

[9] Graveimejer. K.P.E., Local Instruction Theories as Means of Support for Teachers in Reform Mathematics Education. Mathematics Thingking and Learning, 6(2), 125-127, Copyright 2004, Lawrence Eribaum Associates. Inc, 2004.

[10] Freudhental. H., Revisiting Mathematics Education, Utrecht, The Nedherlands: Kluwer Academic, 1991.

[11] Graveimejer. K.P.E., Developing Realistic Mathematics Education, Freudenthal Institute, Utrecht, 1994.

[12] Webb. David C., "Design Research in The Netherlands: Introducing Logarithms Using Reralistic Mathematics Education", Journal of Mathematics Education at Teachers College, SpringSummer 2011, Vol 2, 47-52.

[13] Hidayat, Riyan \& Iksan, Zanaton H., The effect of Realistic Mathematics Education Students' Conceptual Understanding of Linear Programing", Creative Education, 2015, 6, 2438-2445. http://www.scrip.org/journal/ce

[14] Prahmana, Rully C.I \& Kusumah, Yaya. S., "The Hypotetical Learning Trajectory on Research in Mathematics Education Using Research-Based Learning" Pedagogika/ Pedagogy. 2016, t123,Nr.p.42-54/Vol.123. No.3 pp42-54, DOI:http://dx.doi.org/10.15823/p.2016.32, 2016.

[15] Ozkaya, Ali\& Karaca, Sebabat Yetim, "The Effect of Realistic Mathematics Education On Students'Achivements Attitude in fifth Grades Mathematics Course", IOJET 2017,4(2), 2017, 185-197.

[16] Silseth. Kenneth, "The Multivoicedness of game Playing: Exploring the Unfolding of a students'learning trajectory in a gaming context at school" Computer-Supported Collaborative Learning, 2012, 7:63-84 DOI 10.1007/s11412-011-9132-x.

[17] Rees. Mary E., "Developing specialist expertise: an unanticipated learning trajectory" Teacher Development Vol. 13, No. 4, November 2009, 373-383. DOI: 10.1080/13664530903578272 http://www.informaworld.com.

[18] Plomp. T dan N. Nieveen, Educational Design Research. Enshede: Netherlands Institute for Curriculum Development (SLO), 2013.

[19] Gravemeijer. Koeno and Cobb. Paul, "Design research from the Learning Design Perspective", Dalam Jan Ven Den Akker, et. al. Educational Design Research. London: Routledge, 2006.

[20] Turmudi. "Pembelajaran Matematika Kini dan Kecenderungan Masa Mendatang", Bandung: JICA FPMIPA UPI, 2010.

[21] Treffers A, Three Dimensions: A Model of Goal and Theory Description in Mathematics Education (Dordrecht: Reidel), 1991.
[22] de Lange J, Mathematics, Insight, and Meaning (Utrecht: OW \& OC), 1987 